\title{
Assessment of Pollution Trend of Oke Afa Canal Lagos, Nigeria
}

\author{
R. A. OLOWU ${ }^{\S}$, O.O. AYEJUYO ${ }^{\# *}$ G.O. ADEWUYI ${ }^{\#}$, I. A. ADEJORO, \\ T.A. AKINBOLA ${ }^{\S}$, M. O. OSUNDIYA and C.T. ONWORDI ${ }^{\S}$ \\ ${ }^{\S}$ Department of Chemistry, Lagos State University, P.M.B 001, Nigeria. \\ Department of Chemistry, University of Lagos Akoka, Nigeria. \\ \#Department of Chemistry, University of Ibadan, Ibadan, Nigeria. \\ drayejuyo@yahoo.com
}

Received 17 July 2009; Accepted 10 September 2009

\begin{abstract}
The physiochemical properties of Oke Afa water body were investigated. The parameters were compared with established international standard (APCELS). The canal water contained very high concentration of BOD $(64.8 \pm 11.3 \mathrm{mg} / \mathrm{L})$ and COD $(107.8 \pm 22.3 \mathrm{mg} / \mathrm{L})$ which would suggest the presence of a high level of organic load that result in the pollution of the canals. Significant concentration of TSS ranging from $(92 \pm 100 \mathrm{mg} / \mathrm{L}), \mathrm{SO}_{4}{ }^{2-}$ $(9.84 \pm 5.59 \mathrm{mg} / \mathrm{L}), \quad \mathrm{PO}_{4}{ }^{3-}(0.66 \pm 0.33 \mathrm{mg} / \mathrm{L}), \quad \mathrm{Cl}(37 \pm 2.84 \mathrm{mg} / \mathrm{L}), \quad \mathrm{NO}_{3}{ }^{-}$ $(2.63 \pm 0.6 \mathrm{mg} / \mathrm{L})$ and $\mathrm{DO}(0.96 \pm 0.15 \mathrm{mg} / \mathrm{L})$ were observed. Low concentration of zinc and copper were observed except lead that has a higher concentration above the allowed permissible level at a point B of the sampling sites. Some heavy metals were not detected at all in all the sampled points of the canal. The $\mathrm{pH}$ and temperature were fairly constant and the values of conductivity reveal a slight decline in the ability of the water to conduct electricity down the canal. All the detected parameters fell within limits except Lead.
\end{abstract}

Keywords: Physicochemical properties, Pollution, Nigeria, Canal.

\section{Introduction}

Water is probably the most important resource in the world, since without it life will be non existence and industrial activities can not take place. It plays a vital role in the development of communities because a reliable supply of water is an essential pre-requisite for establishment of a permanent community ${ }^{1}$. Over the year however, water, especially in the form of rivers, stream and ocean has traditionally served as a mean of waste disposal of materials such as feaces and other domestic waste products all over the world. As human population increases with a parallel expansion in industrial and agricultural activities, water sources became receiver of wastewater along with contaminants both from home and industries. They renewed or purify themselves by dilution and through a cycle known as hydraulic cycle ${ }^{2}$. The water quality of Nigeria surface water bodies are believed to be 
deteriorating gradually particularly in the industrialized and densely populated area of Lagos state $^{3-5}$. The amount of treated and untreated wastes discharged into water through our daily and industrial activities has deteriorated the water bodies and make them unfit for many of their purposes ${ }^{5}$. Subsequently, our planet is slowly and surely harmed to the point where organisms die at a very alarming rate ${ }^{1}$. In addition to innocent organisms dying off, our drinking water has become greatly affected, which hindered our ability to use water for recreational purposes and game fishing in the communities. The contamination of soil, sediment, water resources and biota by heavy metals has been reported to be of major health and environmental concern, especially in many industrialized countries because of their toxicity, persistence and bioaccumulative nature ${ }^{6}$.

There is a strong relationship between human activities and pollution of the environment. The recognition of this connection and need to protect human health, recreation and fish's production led to early development of water quality regulations and monitoring methods ${ }^{7,8}$. Oke Afa canal is a $3.5 \mathrm{~km}$ stretch long and it drains Isolo in Lagos metropolis, western part of Nigeria. On latitude of $6.45^{\circ} \mathrm{N}$ and longitude $3.47^{\circ} \mathrm{E}$. Till date, Lagos is the economic nerve center of the country and the most populated city in the country.

Furthermore, Lagos has the highest concentration of manufacturing industries in the country with over 3000 industries (small, medium and large). Very close to Oke Afa canal are the Isolo open dump site and the Oke Afa plank market which can serve as point of pollution.

However, this canal is the only one which connects wastewater from industrial areas of Fatai Atere, Ilupeju, Ogba and Ladipo alongside the domestic area of Oshodi Apakun, Shasha and Airport road with mile 2 canals and finally to the Lagos harbour. Virtually all water pollutants are hazardous to human as well as other forms of life. Sodium has been implicated in cardiovascular disease, nitrate in blood disorder while some other contaminants are carcinogenic (DDT). Beaches along coast, riverbanks and lakeshores have been ruined for bathers by industrial waste, municipal sewage and medical waste 9 .

It has been reported that agriculture is the biggest polluter, even more so than industries and municipalities. Farming is responsible for $70 \%$ of current waste pollution in U.S $S^{10}$. Industrial effluents, agricultural run-offs, transport, burning of fossil fuel, animal and human excretion, geological weathering and domestic waste had been reported to have major contribution to the pollution of water bodies ${ }^{5,11}$. The water quality character over two sampling periods, the speciation of metal in the lake water and sediment, the risk to water column contamination and level of heavy metal in largemouth bass sample has been reported ${ }^{6}$. Water pollution is even greater problem in third world countries (like Nigeria) where millions of people obtain water for drinking and sanitation from unprotected canal, stream and pond which are contaminated with human waste. This type of contamination has been estimated to cause more than three million deaths annually from diarrhoea in the third world countries, most of them are children.

Inadequate access to reliable water quality is both a cause and consequence of poverty in developing region such as Africa. A high incidence of communicable disease due to lack of sanitation reduces vitality and economic vitality. Food resources are also threatened by damaged agricultural production, in terms of decreased crop yield and quality through the use of salinized and polluted water for crop irrigation. Aquatic ecosystem will not be able to provide the essential food either. Water pollution has been reported to cause damage in commercial fishes which result in decline in commercial fish production of riverine settlement and the decline is expected to exacerbate a protein element from livestock production and agriculture ${ }^{6}$. 
The objective of this study was to examine the pollution status and pollution trend of Oke Afa canal. This is expected to provide a base line data that will assist or arouse the interest of other scientist or the public on the impact of the canal on its surrounding communities as well as to alert the appropriate agencies on the need to formulate and enforce a comprehensive environmental action plan for Nigerians` sprawling urban cities.

\section{Experimental}

Water samples were collected randomly from the Oke Afa canal (river) between the months of March and April 2006 from five different sampling sites A, B, C, D and E given below.
A $-400 \mathrm{~m}$ before the Shasha river inlet
B - $100 \mathrm{~m}$ after the Shasha river inlet
C $-500 \mathrm{~m}$ after the airport inlet (shortly after the bridge close to the plank market).
D $-1.2 \mathrm{~km}$ after the airport inlet (before a sand mining).
E $-2.5 \mathrm{~km}$ after the airport inlet.

The water samples were as collected following the standard procedure described by the American Public Health Association (1998) and Department of Water Affair and Forestry [DWAF] (1992).

\section{Nature of site}

A plank market is located close to the site $\mathrm{C}$ shortly after the bridge which carries a high mass of pedestrian. Apart from a mining site located around the site D there is a heavy volume of traffic along the airport road traversing this site.

\section{Chemical}

High purity chemicals and reagents were purchased from Merck and Aldrich chemicals company) together with distilled deionised water were used. Standard Stock Solution $\left(1 \mathrm{mg} / \mathrm{dm}^{3}\right)$ were prepared from these chemicals.

\section{Instrumentation}

The determinations of the heavy metal lead $(\mathrm{Pb})$, chromium $(\mathrm{Cr})$, zinc $(\mathrm{Zn})$, nickel $(\mathrm{Ni})$, cadmium $(\mathrm{Cd})$, copper $(\mathrm{Cu})$ was performed by the use of a Buck Scientific 200A Atomic Absorption Spectrometer. The instrument was calibrated with analytical grade metal Standard Stock Solution Akdskk pH and phosphate determination were performed using Jenwi $3150 \mathrm{pH}$ metal model already calibrated with buffers 4 and 7 and DR 2010 spectrophotometer respectively.

\section{Physicochemical analysis}

The temperature was measured using calibrated mercury in glass thermometer $\left(0-100{ }^{\circ} \mathrm{C}\right)$ to the nearest $0.05{ }^{\circ} \mathrm{C}$. Jenwi $3150 \mathrm{pH}$ meter calibrated with buffer solutions 4 and 7 was used for $\mathrm{pH}$ determination. Determination of biochemical oxygen demand (BOD), determination of dissolved oxygen (DO), The determination of chemical oxygen demand (COD), total suspended solid (TSS), total dissolved solid (TDS), hardness, oil and grease, $\mathrm{Cl}^{-}, \mathrm{NO}_{3}^{-1-}, \mathrm{SO}_{4}{ }^{2-}, \mathrm{PO}^{3-}, \mathrm{NO}_{3}^{-}$ were carried out according to standard method for water ${ }^{16,17}$ and wastewater ${ }^{1,5}$.

\section{Results and Discussion}

The sample from point A was very dirty and with water hyacinth all over it. This could be as a result of the large amount of domestic waste coming from Apakun where the Oke Afa canal has its source. The water however becomes clearer between point $\mathrm{C}$ and point $\mathrm{E}$ with less water hyacinth by the side of the canal. 
Septic smell was perceived from the sample collected at point A and was characterized with blackish colour indicating pollution through anthropogenic activities. At points $\mathrm{D}$ and $\mathrm{E}$, no smell was perceived and the colour was light grey.

\section{Temperature and $\mathrm{pH}$}

Temperature and $\mathrm{pH}$ remained fairly constant throughout the canal as shown in Table 1 . The temperature ranged from 27 to $28{ }^{\circ} \mathrm{C}$. The $\mathrm{pH}$ values of the canal were between 6.49 and 6.50 with a mean value of $6.58 \pm 0.07$. The values conform to World Health Standard ${ }^{12}$.

\section{Conductivity}

The conductivity value was at the highest at point A with $420 \mu \Omega / \mathrm{cm}$ and lowest at point $\mathrm{E}$ with $280 \mu \Omega / \mathrm{cm}$. This shows a slight decline in the ability of the water to conduct electricity down the canal. The mean value of $358 \pm$ was observed is above the WHO standard ${ }^{12}$, Organization Standard for Domestic Water (WHO) $)^{12}$.

\section{Total suspended solid}

The concentration of TSS at point A was the highest $(290 \mathrm{mg} / \mathrm{L})$ which may be attributed to the direct discharge of domestic and industrial wastes but went down drastically at point B to $48 \mathrm{mg} / \mathrm{L}$. The drastic rundown in the amount of the suspended solid could be attributed to the filtering of these solids by the roots of the water hyacinths in the water as well as the impact of the Shasha river linking the canal before point B which may have further dispersed the suspended solid. The minimum value of TSS was observed at point E which may be as a result of continuous filters by the root of the water hyacinth. The mean value of the TSS in the Oke Afa canal investigated was $92 \mathrm{mg} / \mathrm{L}$ which is above the APCEL standard ${ }^{4}$.

The highest value of $265 \mathrm{mg} / \mathrm{L}$ was found at point A and declined gradually to $185 \mathrm{mg} / \mathrm{L}$ at point $\mathrm{E}$. The mean value for the TDS $233 \mathrm{mg} / \mathrm{L}$ was observed. The major sources of TSS are toxic organics and heavy metals ${ }^{10}$.

\section{Total solid (TS)}

This is dependent on the TSS and the TDS. The concentration of $520 \mathrm{mg} / \mathrm{L}$ observed at point A maybe attributed to high value of TSS. A similar trend had been reported ${ }^{10}$, The value reduced to $252 \mathrm{mg} / \mathrm{L}$ at point $\mathrm{E}$. The mean value for total solid investigated is $296.6 \pm 113.8 \mathrm{mg} / \mathrm{L}$.

\section{Oil and grease}

The average concentration of oil and grease $(29.6 \pm 3.2 \mathrm{mg} / \mathrm{L})$ in the canal at the point A (point of discharge of domestic water waste) were found to be higher than the permissible limit of $0.3 \mathrm{mg} / \mathrm{L}$ for the domestic water ${ }^{4}$.

\section{Total hardness}

Total hardness of the canal ranged from 66.5 to $80 \mathrm{mg} / \mathrm{CaCO}_{3} / \mathrm{L}$. The mean value fell within the WHO and European Union Standard. A similar trend has been observed ${ }^{3}$.

\section{Dissolved oxygen}

The result for $\mathrm{DO}$ at point $\mathrm{A}$ was $0.80 \mathrm{mg} \mathrm{O}_{2} / \mathrm{L}$ but went up slightly to $1.0 \mathrm{mg} / \mathrm{L}$ at point $\mathrm{B}$ which can be attributed to the turbulence caused by the inflow of the Shasha river just before point $\mathrm{B}$. The value of $0.90 \mathrm{mg} / \mathrm{L}$ was observed at points $\mathrm{C}$ and $\mathrm{D}$ respectively but moved up to $1.20 \mathrm{mg} / \mathrm{L}$ probably due to sand mining activity just before the point. However, the entire observed values fell below the standard ${ }^{4,5}$. 
Table 1. Characteristics of water collected from the canal.

\begin{tabular}{|c|c|c|c|c|c|}
\hline Sampling Point & $\mathrm{A}$ & $\mathrm{B}$ & $\mathrm{C}$ & $\mathrm{D}$ & $\mathrm{E}$ \\
\hline Appearance & $\begin{array}{l}\text { Dirty and turbid } \\
\text { with water hyacinth } \\
\text { on water course }\end{array}$ & $\begin{array}{l}\text { Dirty, less turbid } \\
\text { with water } \\
\text { hyacinth on water } \\
\text { course }\end{array}$ & $\begin{array}{l}\text { Clear with } \\
\text { less water } \\
\text { hyacinth }\end{array}$ & $\begin{array}{c}\text { Clear } \\
\text { with less } \\
\text { water } \\
\text { hyacinth }\end{array}$ & $\begin{array}{c}\text { Clear } \\
\text { with less } \\
\text { water } \\
\text { hyacinth }\end{array}$ \\
\hline $\begin{array}{l}\text { Odour / } \\
\text { Colour }\end{array}$ & Septic/black & Foul/Grey & Foul/Grey & $\begin{array}{c}\text { None/Light } \\
\text { Grey }\end{array}$ & $\begin{array}{c}\text { None/Light } \\
\text { Grey }\end{array}$ \\
\hline Temp $^{\circ} \mathrm{C}$ & 28 & 28 & 27 & 28 & 27 \\
\hline $\begin{array}{l}\text { Conductivity, } \\
\mu \mathrm{mhos} / \mathrm{cm}\end{array}$ & 420 & 360 & 370 & 360 & 280 \\
\hline $\mathrm{pH}$ & 6.49 & 6.62 & 6.65 & 6.63 & 6.51 \\
\hline TSS, mg/L & 290 & 48 & 45 & 39 & 38 \\
\hline TDS, mg/L & 265 & 241 & 242 & 236 & 185 \\
\hline $\mathrm{TS}, \mathrm{mg} / \mathrm{L}$ & 520 & 252 & 266 & 244 & 201 \\
\hline $\begin{array}{l}\text { Oil/Grease, } \\
\mathrm{mg} / \mathrm{L}\end{array}$ & 35 & 30 & 28 & 27 & 28 \\
\hline $\begin{array}{l}\text { Total Hardness } \\
\mathrm{mgCaCO}_{3} / \mathrm{L}\end{array}$ & 78 & 80 & 74 & 66.5 & 68.5 \\
\hline $\mathrm{Cl}^{-} \mathrm{mg} / \mathrm{L}$ & 42 & 36 & 38 & 34 & 35 \\
\hline $\mathrm{DO}, \mathrm{mg} / \mathrm{L}$ & 0.80 & 1.00 & 0.90 & 0.90 & 1.20 \\
\hline $\mathrm{BOD}_{5}, \mathrm{mgO}_{2} / \mathrm{L}$ & 62 & 80 & 76 & 53 & 53 \\
\hline $\mathrm{COD}, \mathrm{mgO}_{2} / \mathrm{L}$ & 93 & 132 & 137 & 95 & 82 \\
\hline $\mathrm{SO}_{4}{ }^{2-}, \mathrm{mg} / \mathrm{L}$ & 18.0 & 14.0 & 9.20 & 5.40 & 2.60 \\
\hline $\mathrm{NO}^{3-}, \mathrm{mg} / \mathrm{L}$ & 4.50 & 3.96 & 3.46 & 3.32 & 2.92 \\
\hline $\mathrm{PO}_{4}{ }^{3-}, \mathrm{mg} / \mathrm{L}$ & 0.96 & 1.14 & 0.53 & 0.31 & 0.35 \\
\hline Lead, mg/L & BDL & 0.360 & BDL & BDL & BDL \\
\hline $\mathrm{Ni}, \mathrm{mg} / \mathrm{L}$ & $\mathrm{BDL}$ & BDL & BDL & BDL & BDL \\
\hline $\mathrm{Cr}, \mathrm{mg} / \mathrm{L}$ & BDL & BDL & BDL & BDL & BDL \\
\hline $\mathrm{Cd}, \mathrm{mg} / \mathrm{L}$ & ND & BDL & BDL & BDL & BDL \\
\hline $\mathrm{Zn}, \mathrm{mg} / \mathrm{L}$ & 0.068 & 0.075 & 0.180 & 0.200 & 0.235 \\
\hline $\mathrm{Cu}, \mathrm{mg} / \mathrm{L}$ & 0.015 & 0.030 & 0.0053 & 0.0091 & 0.016 \\
\hline
\end{tabular}

BDL-Below Detectable Limit

\section{Biological oxygen demand $(B O D)$}

BOD is the measurement of the dissolved oxygen used by micro organism in the biological oxidation of organic matter. High BOD values suggest more waste product or pollutants are present in the sample. The mean concentration of BOD observed in the canal was $64.8 \pm 11.3$ $\mathrm{mg} \mathrm{O}_{2} / \mathrm{L}$. This may be as a result of escape of organic matter (organic) into the canal mostly from faecal waste deposition by the surrounding populace. A similar trend has been observed $^{10}$.

\section{Chemical oxygen demand}

The COD value of the canal investigated ranged from $82 \mathrm{mg} \mathrm{O}_{2} / \mathrm{L}$ to $137 \mathrm{mg} \mathrm{O} / / \mathrm{L}$ with a mean value of $107.8 \pm 22.3 \mathrm{mg} / \mathrm{L}$. The highest value of COD was observed at point $\mathrm{C}$ which could linked with the inflow of Shasha river contained industrial effluent which is being discharged into the canal before point $\mathrm{B}$. The mean values were more than the APCEL standard which is an indication that the canal is polluted ${ }^{4}$. 


\section{Chloride}

The average concentration of $37 \pm 2.83 \mathrm{mg} / \mathrm{L}$ was observed for chloride in the canal and this value fell below the $200 \mathrm{mg} / \mathrm{L}$ recommended by $\mathrm{WHO}^{5,12}$.

Table 2. Water quality standards.

\begin{tabular}{|c|c|c|c|c|c|}
\hline Parameter & $\begin{array}{l}\text { Mean } \\
\text { value }\end{array}$ & WHO & EU & APCEL(A) & APCEL (B) \\
\hline Conductivity, $\mu \mathrm{mhos} / \mathrm{cm}$ & 358 & 250 & 250 & - & - \\
\hline $\mathrm{pH}$ & 6.58 & - & - & $6-8.5$ & $5.5-9$ \\
\hline $\mathrm{TSS}, \mathrm{mg} / \mathrm{L}$ & 92 & - & - & 20 & 80 \\
\hline $\mathrm{TDS}, \mathrm{mg} / \mathrm{L}$ & 233.8 & - & - & - & - \\
\hline $\mathrm{TS}, \mathrm{mg} / \mathrm{L}$ & 296.6 & - & - & - & - \\
\hline Oil/grease, mg/L & 29.6 & - & - & - & 0.3 \\
\hline Total hardness, $\mathrm{mg} \mathrm{CaCO}^{3} / \mathrm{L}$ & 73.4 & - & - & - & - \\
\hline $\mathrm{Cl}^{-}, \mathrm{mg} / \mathrm{L}$ & 37 & 250 & 250 & - & - \\
\hline $\mathrm{DO}, \mathrm{mgO}_{2} / \mathrm{L}$ & 0.96 & - & - & 6 & \\
\hline $\mathrm{BOD}_{5}, \mathrm{mgO}_{2} / \mathrm{L}$ & 64.8 & - & - & $<4$ & $<25$ \\
\hline $\mathrm{COD}_{5}, \mathrm{mgO}_{2} / \mathrm{L}$ & 107.8 & - & - & $<10$ & $<35$ \\
\hline $\mathrm{SO}_{4}^{2-}, \mathrm{mg} / \mathrm{L}$ & 9.84 & 500 & 250 & - & - \\
\hline $\mathrm{NO}_{3-}, \mathrm{mg} / \mathrm{L}$ & 3.63 & 50 & 50 & 10 & 15 \\
\hline $\mathrm{PO}_{4}{ }^{3-}, \mathrm{mg} / \mathrm{L}$ & 0.66 & - & - & - & - \\
\hline Lead, mg/L & 0.072 & 0.01 & 0.01 & 0.05 & 0.1 \\
\hline $\mathrm{Ni}, \mathrm{mg} / \mathrm{L}$ & BDL & 0.02 & 0.02 & 0.1 & 1.0 \\
\hline $\mathrm{Cr}, \mathrm{mg} / \mathrm{L}$ & BDL & 0.05 & 0.05 & 0.05 & 0.05 \\
\hline $\mathrm{Cd}, \mathrm{mg} / \mathrm{L}$ & BDL & 0.003 & 0.005 & 0.01 & 0.02 \\
\hline $\mathrm{Zn}, \mathrm{mg} / \mathrm{L}$ & 0.152 & 3.0 & - & 1.0 & 2.0 \\
\hline $\mathrm{Cu}, \mathrm{mg} / \mathrm{L}$ & 0.015 & 2.0 & 2.0 & 0.1 & 1.0 \\
\hline
\end{tabular}

$B D L$ - Below Detectable Limit

APCEL (A) - Values applied to the surface water used for source of domestic water supply with appropriate treatments.APCEL (B) - Values applied to the surface water used for the purposes other than domestic water supply.

\section{Phosphate and nitrate}

The nitrate concentration of the water sample had a mean value of $3.63 \pm 0.61 \mathrm{mg} / \mathrm{L}$. The values ranged from $2.92 \mathrm{mg} / \mathrm{L}$ at point $\mathrm{E}$ to $4.50 \mathrm{mg} / \mathrm{L}$ at point $\mathrm{A}$. The observed value was below $50 \mathrm{mg} / \mathrm{L}$ stipulated by $\mathrm{WHO}^{12}$. The phosphate concentration of the canal ranged from $0.3 \mathrm{mg} / \mathrm{L}$ to $1.14 \mathrm{mg} / \mathrm{L}$ with a mean value of $0.66 \pm 0.33 \mathrm{mg} / \mathrm{L}$. Both phosphate and nitrate are component of agricultural fertilizer commonly used by farmers within the state. These fertilizers may be leached into the soil and river bodies and this may account for significant concentration observed in this study $1^{1,10}$.

\section{Sulphate}

The mean value observed for sulphate was $9.84 \pm 5.59 \mathrm{mg} / \mathrm{L}$. The highest concentration was found at point $\mathrm{A}$ and the lowest at point $\mathrm{E}$. The results showed a gradual reduction in the sulphate concentration along the canal. The values were within the limit set ${ }^{10}$. 


\section{Heavy metals}

The samples in canal were screened for their heavy metal concentration. The sample was analyzed for nickel, chromium, cadmium, zinc and copper. Nickel, cadmium and chromium were not detected in the canal sample. The concentration of the zinc is worthy of note as it increased from basal level of approximately $0.068 \mathrm{mg} / \mathrm{L}$ at point A to $0.235 \mathrm{mg} / \mathrm{Lat}$ point $\mathrm{E}$. Toxicity identification studies have indicated that zinc may be the primary cause of toxicity in certain contaminated aquatic system ${ }^{5}$. High concentration of zinc has been observed to be specifically toxic to an aquatic insect, Ranitos elongata at $1.658-2.853 \mathrm{mg} / \mathrm{L}$ and in the micro toxic test system $(1.35 \mathrm{mg} / \mathrm{L})^{10}$. Lead was detected only at point $\mathrm{B}$. The concentration obtained is above the allowed permissible limit and accumulation of this metal have been reported to induce abdominal pain, vomiting, drowsiness and paralysis of the liver and brain in human ${ }^{10}$. Copper concentrations were between $0.0019 \mathrm{mg} / \mathrm{L}$ and $0.030 \mathrm{mg} / \mathrm{L}$ with a mean value of $0.015 \pm 0.009 \mathrm{mg} / \mathrm{L}$ in the water sample of the canal. The concentration of zinc and copper detected were with the standard limits.

\section{Conclusion}

The study has shown that water from the Oke Afa canal was polluted especially with municipal waste and other organic pollutants resulting in high concentration of BOD and COD. Apart from lead which was detected only at one point, there was no indication of serious heavy metal pollution of the canal. There was a general decrease in the pollution status of the canal as it flows towards the Mile 2 River. Although, the canal still have itself cleansing capacity, the accumulation of this pollutants can be fatal to both aquatic and human life. Continued discharge of improperly treated effluent, wastewater or faecal deposition may further compound the environmental problem of populace living around the canal. It is therefore advisable to control the amount and state of substances from industries and homes which find their ways into the canal.

\section{References}

1. Ademoroti C M A, Standard method for water and effluent analysis Limited Ibadan, Nigeria, Fludex Press, 1996.

2. Adeniyi A A and Okediyi $\mathrm{O} \mathrm{O}$, Assessing the speciation pattern of lead and zinc in surface water collected from Abegede Creek Ijora Lagos, 2004.

3. Adeniyi A A, Yusuf K A and Okediyi O O, Environ Monit Assess., 2008, 37, 451-458.

4. Asia Pacific Center for Environmental Law. Water quality, surface water standard (TCVN 5942), 1993.

5. ASTM, Annual book of ASTM standard. Water and environmental technology. Philadelphia U.S.A, 1989, 515-580.

6. Chance G W and Harmsen E, Can J Public Health, 1998, 89, 510-515

7. Yusuf K A and Osibanjo O, Pakistan J Sci Ind Res., 2006, 49, 88-89.

8. Charis K B and Abbasi S A, Int J Environ Studies, 2005, 62, 137-145.

9. Goldsmith E and Hilyard N, The earth report. The essential guide to Global ecological issues. Princestern Sloan Incorporation, Los Angeles, 1988.

10. Ikem A, Egiebor N O and Nyavor K, Water, Air and Soil Pollution, 2003, 149, 51-75.

11. Israel A U, Obot I B, Umoren S A, Mkpeine V and Ebong G A, E-Journal of Chemistry, 2008, 5(1), 74-80.

12. World Health Organization (WHO), Our Planet Our Health. Report on the WHO Commission on Health and Environmental Security, San Jose (Costa Rica), 1992, 20-22. 


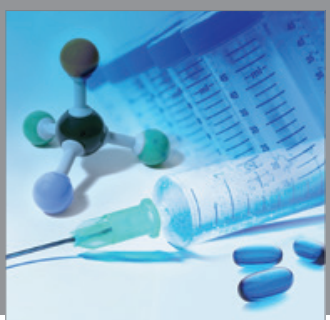

International Journal of

Medicinal Chemistry

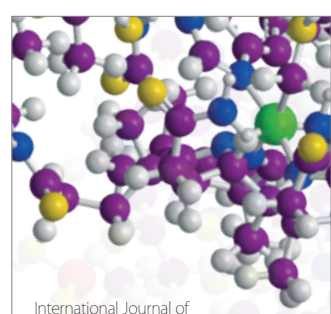

Carbohydrate Chemistry

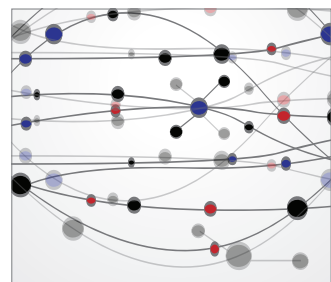

The Scientific World Journal
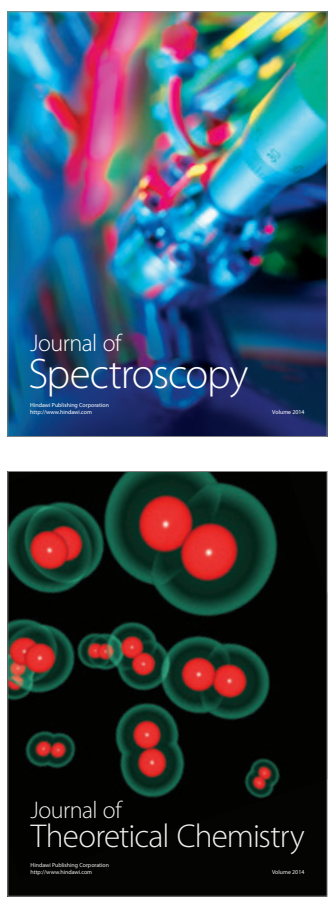
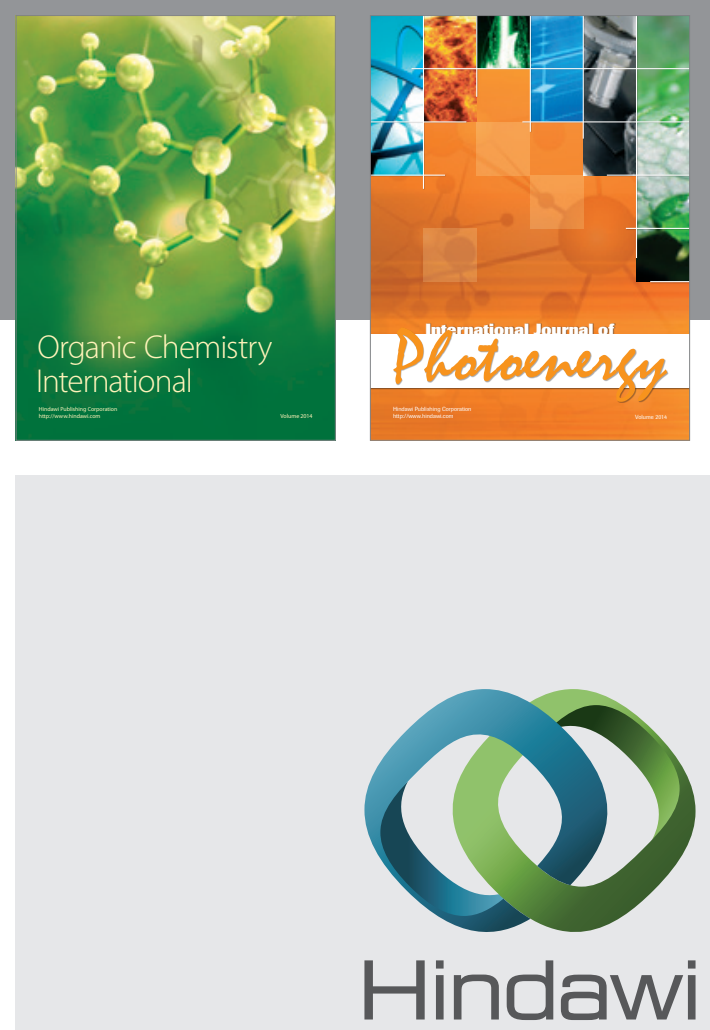

Submit your manuscripts at

http://www.hindawi.com
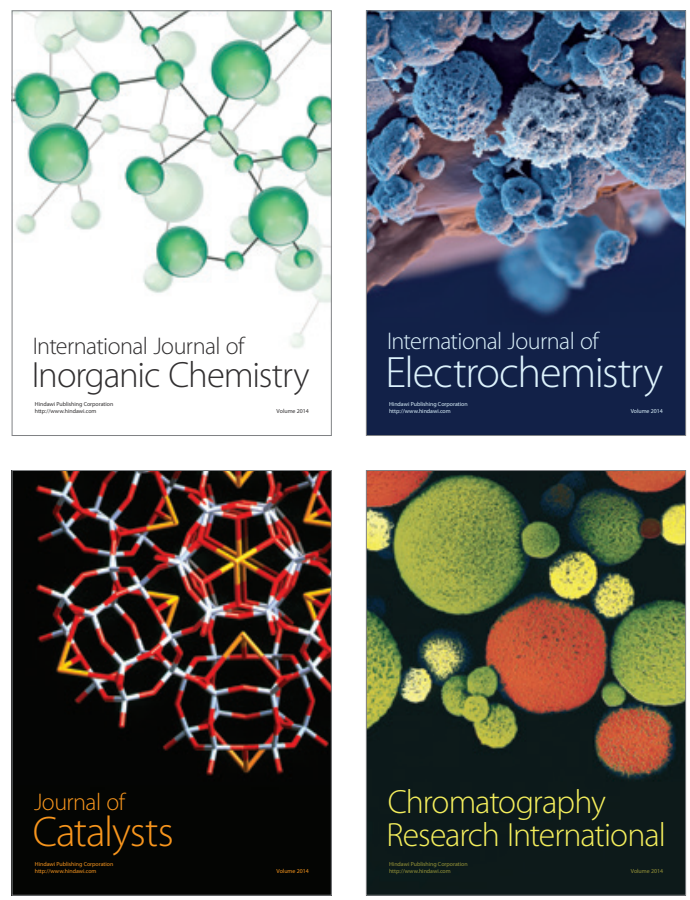
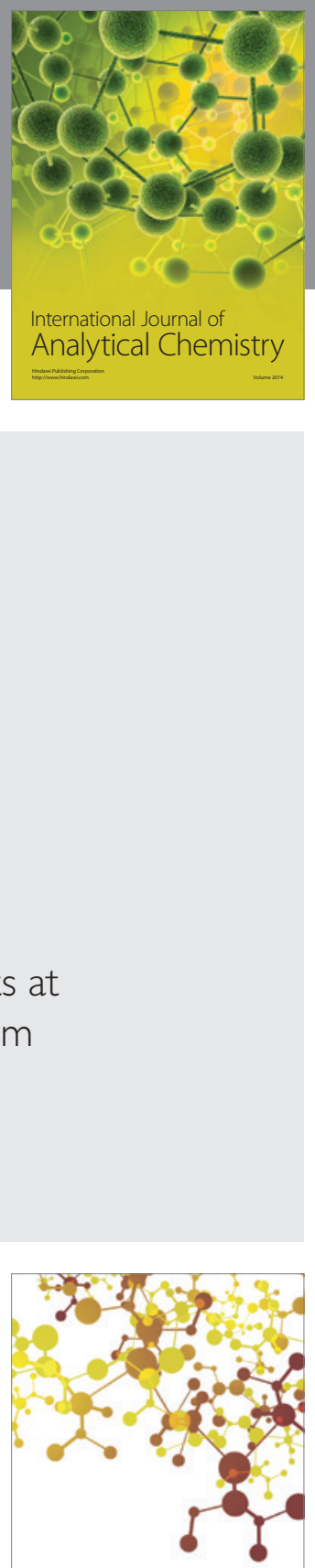

Journal of

Applied Chemistry
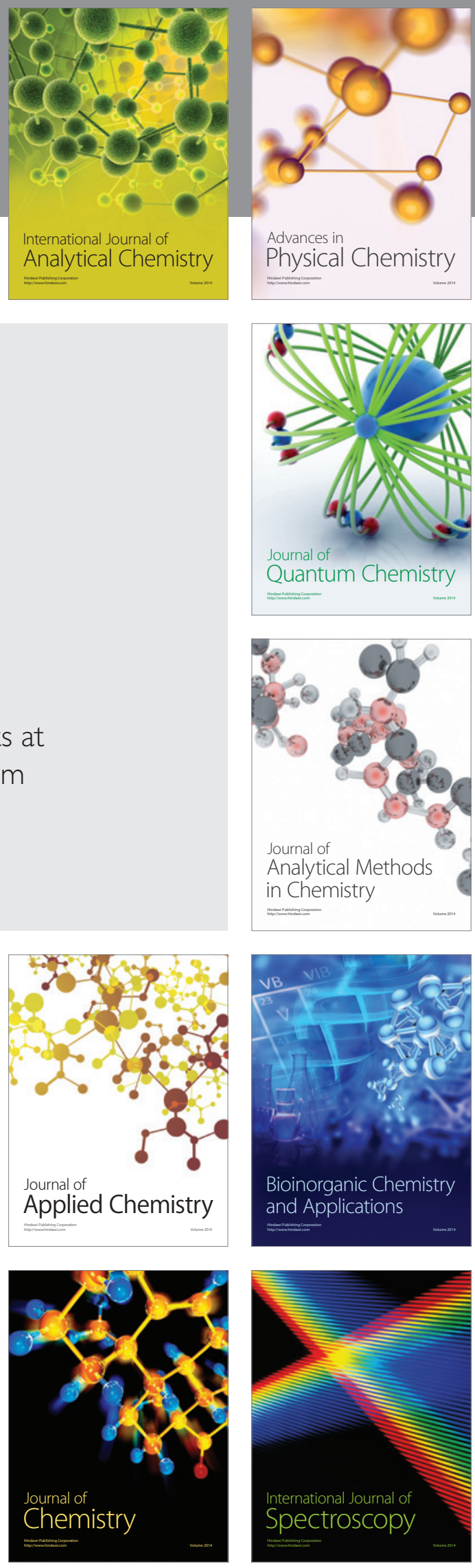